\title{
Molecular typing reveals substantial Plasmodium vivax infection in asymptomatic adults in a rural area of Cameroon
}

Jerome Fru-Cho ${ }^{1,3^{*}}$, Violet V Bumah ${ }^{2}$, Innocent Safeukui ${ }^{3}$, Theresa Nkuo-Akenji ${ }^{1}$, Vincent PK Titanji ${ }^{4}$ and Kasturi Haldar ${ }^{3^{*}}$

\begin{abstract}
Background: Malaria in Cameroon is due to infections by Plasmodium falciparum and, to a lesser extent, Plasmodium malariae and Plasmodium ovale, but rarely Plasmodium vivax. A recent report suggested "Plasmodium vivax-like" infections around the study area that remained unconfirmed. Therefore, molecular and antigenic typing was used to investigate the prevalence of $P$. vivax and Duffy in asymptomatic adults resident in Bolifamba.
\end{abstract}

Methods: A cross-sectional study was conducted from July 2008 to October 2009. The status of all parasite species was determined by nested PCR in 269 blood samples collected. The $P$. falciparum and P. vivax anti-MSP/CSP antibody status of each subject was also determined qualitatively by a rapid card assay. Parasite DNA was extracted from a sample infected with three parasite species, purified and sequenced. The Duffy antigen status of 12 subjects infected with $P$. vivax was also determined by sequencing. In silico web-based tools were used to analyse sequence data for similarities and matches to reference sequences in public DNA databases.

Results: The overall malaria parasite prevalence in 269 individuals was 32.3\% (87) as determined by PCR. Remarkably, $14.9 \%$ (13/87) of infections were caused either exclusively or concomitantly by P. vivax, established both by PCR and microscopic examination of blood smears, in individuals both positive $(50 \%, 6 / 12)$ and negative $(50 \%, 6 / 12)$ for the Duffy receptor. A triple infection by $P$. falciparum, $P$. vivax and $P$. malariae, was detected in one infected individual. Anti-MSP/CSP antibodies were detected in 72.1\% (194/269) of samples, indicating high and continuous exposure to infection through mosquito bites.

Discussion: These data provide the first molecular evidence of $P$. vivax in Duffy positive and negative Cameroonians and suggest that there may be a significant prevalence of $P$. vivax infection than expected in the study area. Whether the $P$. vivax cases were imported or due to expansion of a founder effect was not investigated. Notwithstanding, the presence of $P$. vivax may complicate control efforts if these parasites become hypnozoitic or latent as the liver stage.

Conclusions: These data strongly suggest that $P$. vivax is endemic to the south-west region of Cameroon and should be taken into account when designing malaria control strategies.

Keywords: Asymptomatic malaria, Plasmodium vivax, Duffy, Anti-MSP/CSP antibody, PCR, Genotyping, Bolifamba, Cameroon

\footnotetext{
* Correspondence: jerome.frucho.1@gmail.com; khaldar@nd.edu

${ }^{1}$ Department of Microbiology and Parasitology, University of Buea, Buea,

South West Region, Cameroon

${ }^{3}$ Center for Rare and Neglected Diseases, Department of Biological Sciences

University of Notre Dame du Lac, Notre Dame, Indiana 46556, USA

Full list of author information is available at the end of the article
} 


\section{Background}

Malaria is now second to HIV/AIDS as the global cause of death from infectious diseases, but remains the main global cause of death from parasitic infectious diseases [1]. Malaria threatens approximately half the world's population and causes debilitating illness in more than half a billion people. Morbidity and mortality is particularly high in sub-Saharan Africa, where children below five years are at greatest risk of infection, clinical disease and death $[1,2]$. Yet malaria control strategies have been productive: in 2010, the World Health Organization (WHO) estimated 660,000 deaths due to malaria, indicating a drop of $25 \%$ globally and $33 \%$ in the WHO African Region since 2000 [1]. Plasmodium falciparum remains the deadliest of the malaria parasite species in Africa [1] and also wreaks significant economic havoc in highly endemic areas, substantially decreasing gross domestic product (GDP) of affected countries relative to malaria-free regions $[3,4]$.

With decreases in the falciparum burden, attention must also be focused on more than four hundred million malaria cases due to other parasite species [5], namely Plasmodium vivax, Plasmodium malariae, Plasmodium ovale and, more recently, Plasmodium knowlesi (a simian malaria parasite responsible for a zoonotic form of malaria in humans). Plasmodium vivax is fast becoming a recognized cause of different grades of malaria pathologies on the African continent [6-19], infecting both children and adults, thus threatening the prospect of malaria elimination in parts of Africa. In particular, elimination of asymptomatic malaria is critical for eradication.

There have been two documented reports of infections ascribed to $P$. vivax in Cameroon $[14,18]$. These reports were not in subjects of African origin, but in nonCameroonians who had lived in Cameroon previously and had returned to their home countries several years before the diagnosis indicating asymptomatic carriage. Additionally in 2005, Kimbi and colleagues [20] reported $P$. vivax-like asymptomatic infections in Cameroonian school children with a prevalence of up to $33.3 \%$, but this was diagnosed only by light microscopy. The researchers were not very certain about speciation or species identification capabilities, and thus referred to it as " $P$. vivax -like" asymptomatic infection. This was also due to the notion that Africans for a long time were considered to be refractory to $P$. vivax infection [21], because they lack the Duffy antigen, a receptor needed for $P$. vivax to attach to and invade red blood cells. Unfortunately, there was no follow up on the " $P$. vivax-like" finding and thus there are no conclusive data on the presence of $P$. vivax infections in Cameroon.

Data on the prevalence of Duffy antigen in Cameroonians is also absent. In a bid to bridge this gap in knowledge, the present cross-sectional study was conducted with an aim to detect Plasmodium species and the Duffy status of asymptomatically infected adults. This group is an increasingly important pool for identifying malaria parasite species that remain prevalent in the population even as the burden of febrile (mostly P. falciparum) infections is systematically reduced. The participants were resident in Bolifamba, a multi-ethnic village in the South Western Cameroon rain forest zone.

\section{Methods}

\section{Ethical clearance}

This study was authorized by the South West Regional Delegate of Public Health and the University of Buea Institutional Review Board. All subjects gave signed informed consent before enrollment into the study. All protocols involving human subjects were approved by the IRB of the University of Notre Dame.

\section{Study area}

The study was carried out in Bolifamba, a multi-ethnic rural setting [22] $530 \mathrm{~m}$ above sea level situated on the east slope of Mount Cameroon in the South West Region. Although malaria is endemic throughout Cameroon [23], the country has very different geographical and epidemiologic levels [24]. The epidemiology of malaria in Bolifamba has been well described [22]. Malaria transmission occurs all year round, with peak transmissions during the peak rainy months (July and August). There are two seasons in Bolifamba: the rainy season that runs from March to October and the dry season from November to February. The prevalence of malaria parasitaemia in this area ranges from $30 \%$ in the dry season to $65 \%$ in the rainy season [25]. Plasmodium falciparum accounts for up to $96 \%$ of malaria infections in this area [26], with Anopheles gambiae s.s. being the dominant vector [27]. Hydrologically, a stream runs through the village and is of prime importance to the villagers and to the epidemiology of the disease. In this forested area of Southern Cameroon, the equatorial climate has been modified by the double influence of the ocean and the mountain. The average humidity is constantly high, between $75-80 \%$ or more and temperatures are lower than in the other areas of the southern part of the country; the mean values of the minimum temperatures are $20^{\circ} \mathrm{C}$ in December and $18^{\circ} \mathrm{C}$ in August, the mean values of the maximum temperatures are $35^{\circ} \mathrm{C}$ in August and $30^{\circ} \mathrm{C}$ in March. Notwithstanding, seasons in $\mathrm{Mt}$. Cameroon region have become quite variable in the past decade, with rains beginning in June and lasting until early November, causing some variability in malaria prevalence and transmission patterns [28]. The mountain starts at an altitude of about $50 \mathrm{~m}$ from the coast as a sedimentary plain that extends from Limbe to Mutengene and Tiko. From Mutengene, the terrain gradually elevates to an altitude of $800-1200 \mathrm{~m}$ in Buea town 
[29]. The mountain in Buea, as well as the Limbe Botanic garden and zoo and other recreational sites in Limbe attract tourists of various nationalities. This makes the populations along the Mount Cameroon area highly cosmopolitan. The indigenous inhabitants of Bolifamba are of several ethnic groups [22] and the main occupation is farming. Farm lands extend to the forest areas. By 2005, the population of Bolifamba was assessed to be about 3,500 inhabitants [22].

\section{Study group/study period}

The study group consisted of apparently healthy adults resident in Bolifamba and aged 18-55 years. The subjects had lived in the area for at least five consecutive years. Subjects with signs and symptoms of any chronic illness were not included in the study.

\section{Sample collection}

A door-to-door visit of randomly selected houses was carried out in all the quarters of the Bolifamba village. All participants were non febrile (body temperature below $37.5^{\circ} \mathrm{C}$ ) at time of blood draw. A brief history of malaria infection and management habits was recorded for each subject. Five $\mathrm{mL}$ of blood was collected by venipuncture from each of the 269 subjects enrolled into EDTA containing tubes during the (peak) rainy malaria transmission months throughout the study period (July 2008 to October 2009). The blood was separated into plasma and red cell components by spinning in a Beckmann $^{\odot}$ centrifuge (Beckmann ${ }^{\oplus}$, State Technology Inc, Bridgeport NJ, USA) at $2500 \mathrm{rpm}$ for $5 \mathrm{~min}$.

\section{Parasitological examination}

Thick and thin blood smears were prepared from a small portion of whole blood of each subject on the same slide according the methods previously described [30-32]. The thin blood smears were methanol-fixed and both smears stained with Giemsa stain and examined under the oil immersion lens (x100) and x10 eye piece of an Olympus ${ }^{\circledR}$ light microscope. Parasitaemia was evaluated as previously described [31]. Essentially, with each positive smear, the level of parasitaemia was estimated by counting the parasites against at least 200 leucocytes and then using the leucocyte (WBC) count to estimate the number of parasites/ $\mu \mathrm{L}$ of whole blood while assuming an average of $8,000 \mathrm{WBCs} / \mu \mathrm{L}$ of whole blood as shown in equation 1 .

$$
\begin{aligned}
\text { Parasite Density }= & \frac{\text { Number of Parasite Counted }}{\text { Number of WBCs }} \\
& \times \text { WBC }(800 \text { cells }) \text { per } \mu \text { l Blood. }
\end{aligned}
$$

\section{Anti MSP/CSP antibody card assay}

As a measure of exposure of the subjects to malaria (through infective bites of mosquitoes), the antibody status of each subject was assessed qualitatively by a rapid immunochromatographic card assay detecting either antibodies to the merozoite surface protein (MSP) or the circumsporozoite protein (CSP) (International ImmunoDiagnostics, CA, USA). The assay was carried out as described by the kit manufacturers (International ImmunoDiagnostics, CA, USA). Briefly, $10 \mu \mathrm{L}$ of plasma sample was added to a sample well and 3 drops of the supplied assay diluent added immediately to the same sample well and then allowed to migrate by capillary action. Results were interpreted within 10-20 minutes of adding plasma and assay diluent. The appearance of a visible band corresponded to plasma reactivity with either P. falciparum or $P$. vivax antigens, or both. An additional control band always appeared as an internal control to enable validation of assay results and/or to ascertain that the test card was not faulty in production. When no internal control band was seen, even when the test band(s) appeared, the assay result was discarded and repeated using a fresh card.

\section{Nested polymerase chain reaction (PCR)}

Plasmodium speciation was done for all the 269 subjects using the Nested Polymerase Chain Reaction (PCR) method described by Kimura et al., [33] with some modifications. The Phusion ${ }^{\circ}$ blood PCR kit was used for the Nest 1 reaction. This enabled the amplification of parasite DNA directly from $0.003 \%$ of frozen packed red cells. All PCRs were carried out in a total volume of $20 \mu \mathrm{L}$. The reaction mixture had final concentrations of $\mathrm{MgCl}_{2}$ (3.0 mM), $200 \mu \mathrm{M}$ of each dNTP, $0.25 \mathrm{pmol} / \mu \mathrm{L}$ of each primer, $2.5 \mathrm{mM}$ EDTA, 5\% DMSO, 0.4 U Phusion Blood II DNA Polymerase. The cycling parameters for the Nest 1 reaction using the $\mathrm{PTC}-100$ programmable thermal cycler (MJ. Research Inc., Waltham. MA, USA) were as follows: 1) Lysis of cells/initial denaturation $98^{\circ} \mathrm{C}$ for $5 \mathrm{mi}$ nutes; 2) Denaturation at $98^{\circ} \mathrm{C}$ for $1 \mathrm{sec}$; 3) Annealing at $72^{\circ} \mathrm{C}$ for $15 \mathrm{sec}$; 4) Extension $72^{\circ} \mathrm{C}$ for $30 \mathrm{sec}$; 5) Repeat steps 2-4 for a total of 35 times; 6) Final annealing at $72^{\circ} \mathrm{C}$ for 10 minutes and 7) $4^{\circ} \mathrm{C}$ indefinitely.

For the Nest 2 reaction the TaKaRa kit (TaKaRa Ex $\mathrm{Taq}^{\mathrm{Tm}}$, Hot Start Version) with the high fidelity HS Taq polymerase was used instead of the Phusion ${ }^{\circ}$ blood kit. All PCRs were also carried out in a total volume of $20 \mu \mathrm{L}$. The reaction mixture had final concentrations of $\mathrm{MgCl}_{2}(2.005 \mathrm{mM}), 150 \mu \mathrm{M}$ of each dNTP, $0.25 \mathrm{pmol} /$ $\mu \mathrm{L}$ of each primer, $0.05 \mathrm{U}$ Taq HS DNA Polymerase. Two micro liters of a 1:50 dilution of the Nest 1 amplicon in MiliQ water (MiliQ system) was used as template in the Nest 2 reaction. The cycling parameters for the Nest 2 reaction using the PTC-100 programmable thermal cycler (MJ. Research Inc., Waltham. MA, USA) were 
as follows: 1) Initial denaturation $98^{\circ} \mathrm{C}$ for 5 minutes; 2) Denaturation at $98^{\circ} \mathrm{C}$ for $1 \mathrm{sec}$; 3) Annealing at $60^{\circ} \mathrm{C}$ for $15 \mathrm{sec}$; 4) Extension $60^{\circ} \mathrm{C}$ for $30 \mathrm{sec}$; 5) Repeat steps $2-4$ for a total of 18 times; 6) Final annealing at $60^{\circ} \mathrm{C}$ for 10 minutes and 7) $4^{\circ} \mathrm{C}$ indefinitely. The sequence of oligonucleotides used in both the NEST 1 and 2 reactions were as previously published [6,33].

\section{Analysis of the amplified gene products}

The Nest 2 amplicon was separated on a $2 \%$ agarose gel and a gel picture taken under UV light. All buffers and gel preparations were as described by Sambrook et al. [34].

\section{Purification and quantification of amplified DNA}

The malaria parasite species bands were extracted from the gel for one subject with triple infection and purified using the QIAquick Gel Extraction Kit essentially as described by the manufacturer (Qiagen ${ }^{\odot}$ ). Five (5) $\mu \mathrm{L}$ of the purified DNA was run on a $2 \%$ agarose gel to ascertain purity and for semi-quantification.

\section{Sequencing/genotyping of the purified parasite DNA and} DARC gene promoter DNA fragment

A sequencing order for all DNA to be sequenced was submitted (on line) to the sequencing and genotyping facility of the University of Chicago cancer center [35] and the appropriately labeled samples sent to the facility by postal mail service.

\section{Bioinformatics (in silico) analyses of the sequenced parasite DNA}

The finished sequences were downloaded from the University of Chicago comprehensive cancer center web page [36], cleaned and used in a BLASTn algorithm against the GenBank reference genomic sequence of Plasmodium available at the NCBI web page [37] and the output file showing the hits and similarity profile copied and saved.

\section{Duffy blood group determination}

To detect the point mutation $-33 \mathrm{~T} \rightarrow \mathrm{C}$, which corresponds to a Duffy-negative phenotype, the DARC gene promoter region of 13 subjects were amplified directly from frozen packed red and white cells by PCR, followed by wet lab enzymatic restriction digestion with StyI (New England Biolabs, Ipswich, MA), as well as in silico StyI enzymatic restriction digestion.

The PCR was done with primer pairs previously published [6] with a slight modification of the PCR constituents. The $224 \mathrm{bp}$ fragment was amplified directly from diluted packed red cells or neat plasma using the Direct PCR Blood Phusion ${ }^{\circledR}$ kit (Thermo Scientific) according to the manufacturer's instructions. All reactions were carried out in a total volume of $20 \mu \mathrm{L}$. The reaction mixture had final concentrations of $\mathrm{MgCl}_{2}(3.0 \mathrm{mM}), 200 \mu \mathrm{M}$ of each dNTP, $0.25 \mathrm{pmol} / \mu \mathrm{L}$ of each primer, $2.5 \mathrm{mM}$ EDTA, 3\% DMSO, 0.4 U Phusion Blood II DNA Polymerase and $0.5 \mu \mathrm{L}$ of $0.001 \%$ packed red cells. The cycling parameters using the PTC-100 programmable thermal cycler (MJ. Research Inc., Waltham. MA, USA) were as follows; Lyses of cells/initial denaturation $98^{\circ} \mathrm{C}$ for $5 \mathrm{mi}$ nutes, Denaturation at $98^{\circ} \mathrm{C}$ for $1 \mathrm{sec}$, Annealing at $59^{\circ} \mathrm{C}$ for $15 \mathrm{sec}$, Extension $72^{\circ} \mathrm{C}$ for $30 \mathrm{sec}$, Repeat steps 2-4 for a total of 35 times, final annealing at $72^{\circ} \mathrm{C}$ for 10 minutes and $4^{\circ} \mathrm{C}$ forever.

\section{Analysis of the amplified gene products}

The amplicons were separated on a $2 \%$ agarose gel alongside a $100 \mathrm{bp}$ DNA ladder and the gel photographed under UV light. All buffers and gel preparations were as described by Sambrook et al. [34].

\section{Purification and quantification of the amplified $224 \mathrm{bp}$ DARC gene promoter DNA fragment}

The $224 \mathrm{bp}$ band corresponding to the DARC gene promoter fragment was extracted from the gel and purified using the QIAquick Gel Extraction Kit essentially as described by the manufacturer (Qiagen ${ }^{\circ}$ ). Five $\mu \mathrm{L}$ of the purified DNA was run on a $2 \%$ agarose gel to ascertain purity and for semi-quantification.

\section{Bioinformatics (in silico) analyses of the sequenced DARC gene promoter fragment}

The sequences were downloaded from the University of Chicago comprehensive cancer center web page [36], cleaned and used in a multiple sequence alignment of the 12 subjects' DARC gene promoter sequences on the NCBI web site against the DARC gene promoter Duffy positive consensus sequence downloaded from the NCBI web page. The output file showing the alignment profile was copied and saved.

\section{Wet lab Styl restriction digestion of the amplified DARC gene promoter fragment}

In order to assess by another means whether the fragments amplified from the various subjects contained the sought $\mathrm{T} \rightarrow \mathrm{C}$ point mutation that confers the Duffy negative phenotype, a portion of the gel purified DNA was digested with the enzyme Styl, (New England Biolabs, NEB labs). This enzyme will cut the $224 \mathrm{bp}$ fragment at 2 recognition sites to produce 3 restriction fragments of sizes 82,77 and $64 \mathrm{bp}$, for Duffy positive genotypes or will cut at 3 recognition sites, producing 4 restriction fragments of sizes 82, 65, 64 and $12 \mathrm{bp}$, if the subject is Duffy negative. In Duffy negative subjects, the point mutation in the DARC promoter gene segment creates an additional restriction site for StyI in the 77 bp fragment, breaking it into the 65 and $12 \mathrm{bp}$ fragments. 
The restriction reaction was preformed according to the kit manufacturer's instructions. Briefly, $10 \mu \mathrm{L}$ of each purified DNA was used in the restriction mixture comprising $5 \mu \mathrm{L}$ of miliQ water, $2 \mu \mathrm{L}$ of $10 \mathrm{X}$ Bovine serum albumin (BSA), $2 \mu \mathrm{L}$ of 10X NEBuffer 3 , and $1 \mu \mathrm{L}$ of StyI enzyme. The $20 \mu \mathrm{L}$ total restriction volume in a $1.5 \mathrm{~mL}$ eppendorf tube was incubated in pre-heated water in the wells of a heating block at $37^{\circ} \mathrm{C}$ for at least 1 hour. The entire $20 \mu \mathrm{L}$ tube content for each subject was mixed with $5 \mu \mathrm{L}$ of $6 \mathrm{x}$ Orange G DNA loading dye (Sigma) and loaded onto a $20 \%$ DNA polyacrylamide gel (prepared as described by Sambrook et al. [34]), along with a 100 bp DNA ladder (Promega). The gel was run at $50 \mathrm{~V}$ for 3 hours. The bands were visualized under UV light on a Trans-illuminator.

\section{In silico Styl restriction digestion of the DARC promoter sequences}

Given that the wet lab separation of the restriction product of the 20\% native DNA PAG could be very dubious, the full DARC promoter sequence of each subject was subjected to in silico restriction digestion with the same enzyme (StyI) that was used in the wet lab analysis in order to confirm or refute the more convincing sequence alignment profile relative to the restriction electrophoregraph. This was done using NEBcutter 2 software freely available on the web. Each subject's full length amplified DARC DNA sequence was interrogated with in silico StyI restriction enzyme and the restriction map showing number of restriction sites copied.

\section{Statistical analyses}

The data were analysed using the Statistical Package for Social Sciences (SPSS) version 17.0 (Chicago, IL USA), and the Microsoft Excel 2010 (Microsoft Corporation). The Chi-Square test and the Pearson's correlation were used to find correlation between categorical and numeric variables respectively. Statistical significance was set at $p \leq 0.05$. Multiple sequence alignments were done using freely available web-based ClustalW software. The free web based NEBCutter 2 software was also available for in silico enzymatic restriction digestion. Sequences for analyses were either reversed or reverse complemented using free web-based softwares. Reference sequences were downloaded from respective public databases.

\section{Results}

Detection of Plasmodium vivax and Plasmodium falciparum infection by Giemsa

Representative examples of thin films positive by Giemsa staining confirmed malarial infection suggestive of $P$. falciparum as well as other species (see Figure 1). Unfortunately, some of the morphologies shown in Figure 1 do not show hallmark characteristics of any species. Figure 1
B and $\mathrm{C}$ are not likely to be $P$. falciparum because they are trophozoite stage parasites and schizont stages seen in peripheral circulation. Figure $1 \mathrm{D}$ does show a characteristic $P$. falciparum ring, but convincing speciation required additional analyses.

\section{Detection of anti-parasite antibodies to $P$. vivax and $P$. falciparum in asymptomatic subjects}

To determine whether $P$. vivax was present in our samples, at first pass they were examined using antigens that will bind to both $P$. vivax and $P$. falciparum specific antibodies. This was done using qualitative anti-MSP/CSP antibody immunochromatographic card tests that distinguish between antibodies to both the MSP/CSP of P. falciparum and $P$. vivax. Based on this anti MSP/CSP antibody card assay, the overall prevalence of malaria exposure was $72.1 \%(194 / 269)$. The prevalence of single and mixed Plasmodium antibodies is shown on Table 1. The vast majority (66\%) of samples indicated exposure to $P$. falciparum alone, $\sim 1 \%$ exposure to $P$. vivax and about $4 \%$ exposure to both.

\section{Detection of malaria species in asymptomatic subjects by nested PCR}

Since $P$. malariae can also be found in Cameroon but not detected by the antigen kit, PCR analysis was used for definitive analysis on speciation (Figure 2). Of 269 samples collected, 66 were positive for $P$. falciparum (Table 2). Notably nine were positive for $P$ vivax, four were positive for $P$. malariae and none contained $P$. ovale alone. Three were double positive $P$. vivax and $P$. falciparum another four showed both $P$. malariae and falciparum. One was triply positive for $P$. malariae, $P$. falciparum and $P$. vivax and here the primary data are shown in Figure 2. These bands were isolated and sequenced to confirm the simultaneous presence of all three species based on similarity scores (Figure 3). Although parasite morphology on the $P$. vivax positive smears (Figure 1, Panels A-C) did not all show landmark features of $P$. vivax-infected erythrocytes, the fact that they were read from slides that were solely positive for $P$. vivax by PCR was a confirmation that the parasites seen were indeed $P$. vivax. In Figure 1, Panel D shows a typical $P f$ ring from a sample that was PCR positive for just $P$. falciparum.

BLASTn analyses of the DNA sequences generated from the sample with triple bands on Figure 2 confirmed that the $P$. falciparum, $P$. vivax and $P$. malariae bands matched the Genbank P. falciparum isolate SF4 $18 \mathrm{~S}$ ribosomal RNA gene partial sequence ID: gb| JQ627152.1|, P. vivax isolate SV6 $18 \mathrm{~S}$ ribosomal RNA gene partial sequence ID: gb|JQ627158_1|, and P. malariae type 2 small subunit ribosomal RNA gene complete sequence 

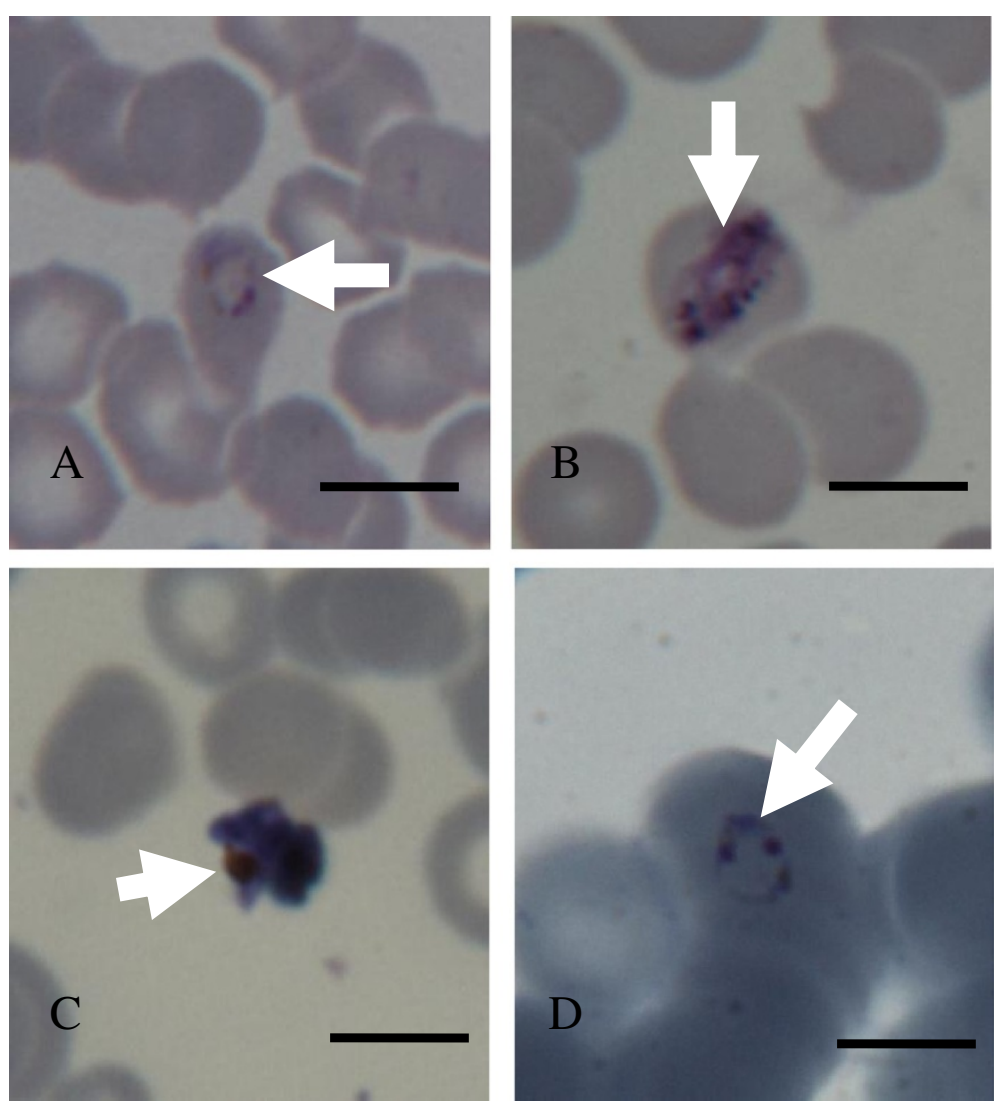

Figure 1 Parasites images (arrow heads) from Pv positive (panels A-C) and Pf positive (panel D) slides. Panel A shows a young trophozoite or late ring stage parasite in an intact red cell. Panel $\mathbf{B}$ shows a late stage P. vivax (PV) trophozoite in an intact red blood cell. Panel $\mathbf{C}$ shows a schizont out of the red cell that does not look healthy. Panel $\mathbf{D}$ shows a typical $P$. falciparum (Pf) ring-stage parasite with double chromatin dots and pale blue cytoplasm. Scale bars $=10 \mu \mathrm{m})$.

ID: $\mathrm{gb}|\mathrm{AF} 488000.1|$ by $100 \%, 97 \%$, and $100 \%$ respectively (Figure 3 ).

Overall there were as many as 87 infected of a total of 269 participants, suggesting as many as a third of asymptomatic patients at this site may contain parasite reservoirs. There were many cases where the subjects were positive for parasite by PCR but negative for anti-MSP/ CSP antibodies $(9.3 \%, 25 / 269)$. This may be due to very low levels of both $P$. falciparum and $P$. vivax infection and suggests that almost a third of the $P$. vivax infections are truly asymptomatic in absence of an antibody response.

\section{Duffy antigen typing}

Having recoded a number of $P$. vivax positive cases among the study subjects by Nested PCR and confirmed by microscopy and sequenced data, the Duffy genotype of the 13 subjects with either $P$. vivax single or mixed infections was investigated. The 224 bp DARC gene promoter fragment was successfully amplified in all the samples. Each subjects' DARC promoter DNA sequence interrogated with in siliso StyI restriction enzyme showed that StyI cut the Duffy positive promoter DNA sequence at two sites, producing three fragments of 82,77 and

Table 1 Distribution of malarial species detected by the card test

\begin{tabular}{lll}
\hline $\boldsymbol{P}$. falciparum & P. vivax & P. falciparum $+\boldsymbol{P}$. vivax \\
\hline $\begin{array}{l}\text { Percent fraction of total samples } \\
\text { shown in parenthesis* }\end{array}$ & Percent fraction of total samples shown in parenthesis* & Percent fraction of total samples shown in parenthesis* \\
\hline $180(66.9)$ & $3(1.1)$ & $11(4.1)$ \\
\hline
\end{tabular}

*Total number of subjects (269).

Table 1 shows the numbers of samples (and the percent fraction of total samples) showing single, mixed infection as detected by MSP/CSP antibody card assay. A total of 269 samples were subjected to the Card test (see Methods). 


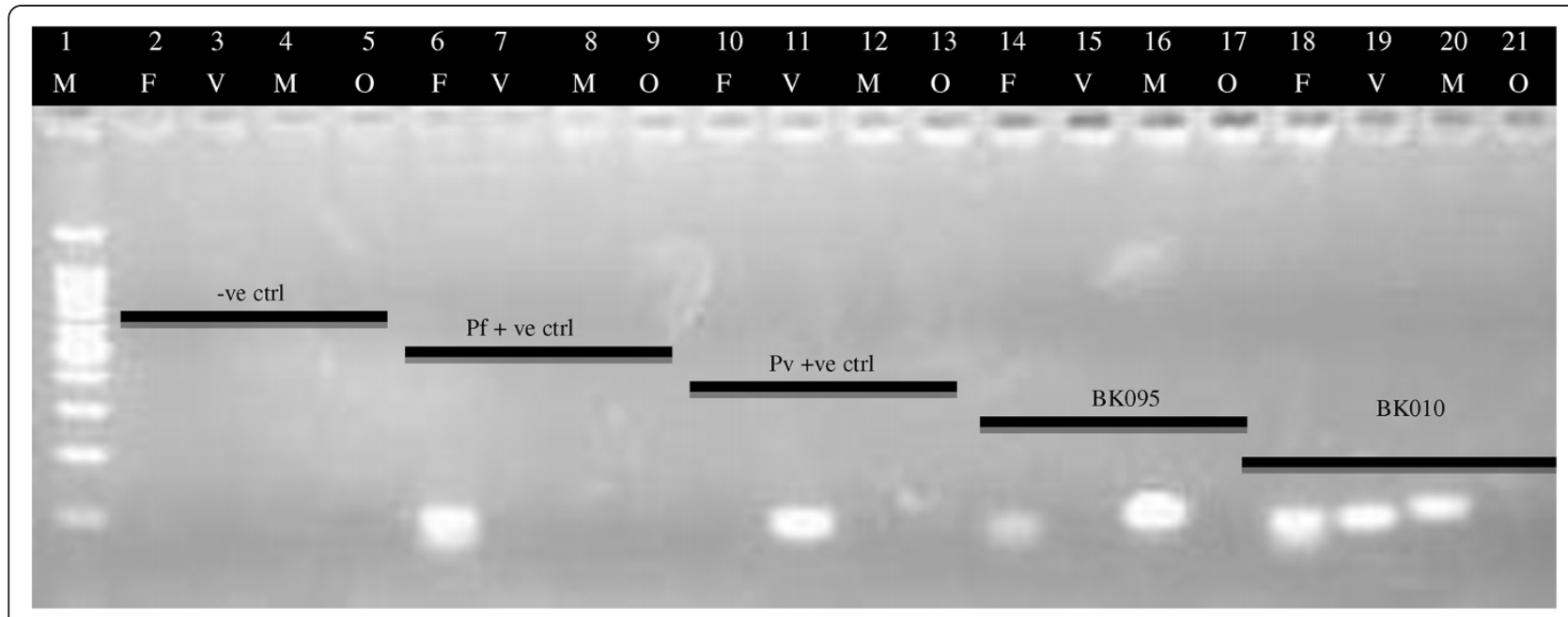

Figure 2 A typical electrophoregram showing Plasmodium species banding patterns after the Nest 2 reaction. In this experiment, a master mix was prepared to amplify Plasmodium DNA in all the samples in the Nest 1 reaction. After the Nest 2 amplification protocol, the amplicons were then separated on a $2 \%$ agarose gel (see methods for more details). $M=100$ bp Ladder, $F=P$. falciparum, $V=P$. vivax, $M=P$. malariae, $\mathrm{O}=P$. ovale. - ve $c t r l=$ Negative control (MiliQ water), $P f+v e=P$. falciparum positive control DNA, $P v+$ ve $=P$. vivax positive control DNA, BK095 \& BK010 are 2 subjects' samples.

64 bp (Figure 4) while the Duffy negative promoter DNA sequence was cut additionally at a site created by the $\mathrm{T} \rightarrow \mathrm{C}$ point mutation in the $77 \mathrm{bp}$ fragment, thereby producing 4 fragments of $82,12,65$, and 64 bp (Figure 4). Multiple sequence alignment of the sequenced DARC promoter gene fragments for 12 of the 13 assessed subjects; alongside a Duffy positive consensus sequence showed the $\mathrm{T} \rightarrow \mathrm{C}$ point mutation which confers the Duffy negative phenotype (Figure 5). This established the prevalence of Duffy positive individuals in the present investigation at $50 \%(6 / 12)$. One case was lost and could not be analysed.

\section{Discussion}

\section{Detection of malaria parasites in asymptomatic} populations

Three methods, namely Giemsa staining, antibodies and PCR, were used to detect parasites in asymptomatic individuals. The overall prevalence of anti-parasite antibodies

Table 2 Mono and multiple infecting Plasmodium species in the studied subjects by PCR

\begin{tabular}{|c|c|}
\hline & $2008 \%$ (n/Total n) \\
\hline$P f$ & $24.5(66 / 269)$ \\
\hline$P V$ & $3.3(9 / 269)$ \\
\hline$P m$ & $1.5(4 / 269)$ \\
\hline Po & $0.0(0 / 269)$ \\
\hline$P f+P v$ & $1.1(3 / 269)$ \\
\hline$P f+P m$ & $1.5(4 / 269)$ \\
\hline$P f+P v+P m$ & $0.4(1 / 269)$ \\
\hline
\end{tabular}

$P f=P$. falciparum; $P v=P$. vivax; $P m=P$. malariae. was relatively high $(72.1 \%)$ but this largely reflected the fact that subjects were constantly exposed to infective bites of mosquitoes or sustained an immune response after active infection. Nonetheless this test and Giemsa gave the first clue that the study subjects may be infected with $P$. vivax parasites. However PCR clearly established that about a third of the study population was infected with malaria parasites. This suggests an unexpectedly high level of asymptomatic infection. Further a substantial portions of infections $(\sim 15 \%)$ contained $P$. vivax. Nonetheless this was lower than the $33.3 \%$ prevalence of microscopically diagnosed " $P$. vivax-like" infection described by Kimbi et al. [20]. It was surprising that $P$. ovale failed to be detected, since other reports in the area that have documented the presence of P.ovale [20,22,38]. As follow-up of the findings in the present study, the wider existence of P. vivax in Bolifamba and Cameroon should be further ascertained.

\section{Plasmodium vivax in Africa}

The present report documents the first substantiated evidence of $P$. vivax infection in Cameroonian Bolifamba residents, in the SWR of Cameroon, raising the number of infecting human Plasmodium species in Cameroonians to four. There have been other reports of $P$. vivax elsewhere on the African continent where $P$. vivax was initially thought to be non-existent or that the population was refractory to infection. These countries include Angola [6], Equatorial Guinea [6,7], Madagascar [8], Mauritania [9], Sudan [10], Kenya [11], Sao Tomé and Principe [12-15], Congo [14], Mali [16], and Ethiopia [17]. Although the exact prevalence data for $P$. vivax in Africa is 
Plasmodium falciparum isolate SF4 18 S ribosomal RNA gene, partial sequence Sequence ID: gb|JQ627152.1 Length: 1921 Number of Matches: 1

\begin{tabular}{|c|c|c|c|c|c|c|c|}
\hline $\begin{array}{l}\text { Score } \\
116 \mathrm{~b}\end{array}$ & $\operatorname{ts}(128)$ & & $\begin{array}{l}\text { Expect } \\
5 e-26\end{array}$ & $\begin{array}{l}\text { Identities } \\
64 / 64(100 \%)\end{array}$ & $\begin{array}{l}\text { Gaps } \\
0 / 64(0 \%)\end{array}$ & $\begin{array}{l}\text { Strand } \\
\text { Plus/Plu }\end{array}$ & \\
\hline $\begin{array}{l}\text { Que Iy } \\
\text { Sbjet }\end{array}$ & $\begin{array}{l}4 \\
1063\end{array}$ & \multicolumn{5}{|c|}{ 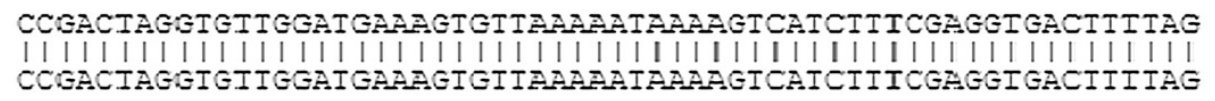 } & 1122 \\
\hline Query & 64 & \multirow{2}{*}{$\begin{array}{l}\text { ATTG } \\
\mid \operatorname{ITTG}\end{array}$} & 67 & & & & \\
\hline Sbjct & 1123 & & 1126 & & & & \\
\hline
\end{tabular}

Plasmodium vivax isolate SV6 18 S ribosomal RNA gene, partial sequence Sequence ID: gb|J0627158.1] Length: 1965 Number of Matches: 1

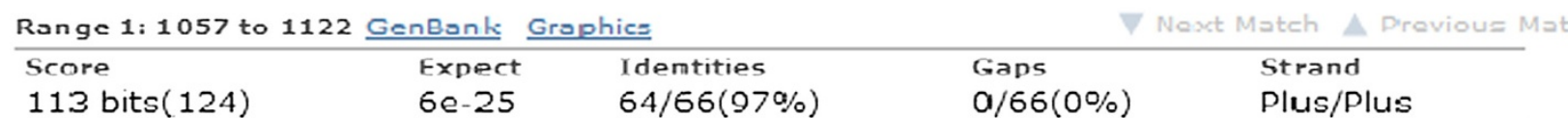

\begin{tabular}{|c|c|c|c|c|}
\hline Query & 1057 & \multicolumn{2}{|c|}{ 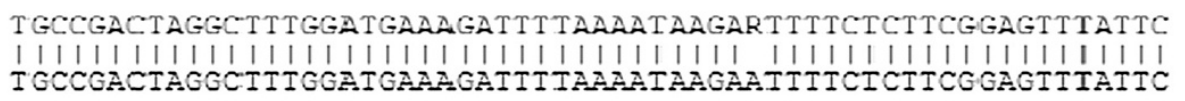 } & 1116 \\
\hline Query & 61 & CTAGAT & 66 & \\
\hline Sbjct & 1117 & ITAGAI & 1122 & \\
\hline
\end{tabular}

\section{Plasmodium cf. malariae type 2 small subunit ribosomal RNA gene, complete sequence sequence ID: gb|AF488000.1] Length: 2156 Number of Matches: 2}

\begin{tabular}{lclll} 
Range $1: 1139$ to 1215 GenBank & \multicolumn{2}{l}{ Graphics } & \multicolumn{1}{l}{ Next Match } & Previous Match \\
\hline Score & Expect & Identitics & Gaps & Strand \\
140 bits(154) & $6 e-33$ & $77 / 77(100 \%)$ & $0 / 77(0 \%)$ & Plus/Plus
\end{tabular}

\begin{tabular}{|c|c|c|c|c|}
\hline $\begin{array}{l}\text { Query } \\
\text { Sbjet }\end{array}$ & 1139 & \multicolumn{2}{|c|}{ 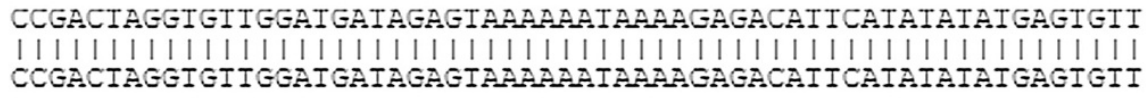 } & $\begin{array}{l}63 \\
1198\end{array}$ \\
\hline Query & 64 & TCTITTAGATAGCTICC & 80 & \\
\hline Sbjct & 1199 & ICITITAGAIAGCIICC & 1215 & \\
\hline
\end{tabular}

Figure 3 BLASTn output of the sequences generated from the triple Plasmodium infected subject. Here, each of the sequences was queried against the Plasmodium GeneBank data and number of hits with percentages identities displayed. For the three sequences, the Gene Bank ID of the reference sequences are shown in blue starting with "gb" for GeneBank.

not known, the parasites seem to be more prevalent in countries where many Duffy positive people are permanent residents $[8,9,11]$. However, the Duffy negative status has been plausibly shown not to be a barrier to $P$. vivax infection as previously believed [8] and confirmed in other studies $[6,9]$, as well as the current one. The increasing prevalence of $P$. vivax on the African continent and its discovery in Cameroonians could be inversely correlating to the decreasing prevalence of $P$. falciparum as a result of targeted control of the latter relative to the other malaria parasite species. A similar phenomenon has been documented in Malaysia, where an increasing incidence of $P$. knowlesi is being linked to the control of P. falciparum and P. vivax [39].

\section{The Duffy phenotype}

With the notion that the Duffy antigen is necessary for the invasion of $P$. vivax into red cells, the Duffy genotype of all the subjects who were positive for $P$. vivax was assessed. Six (6) of the P. vivax infected subjects were Duffy positive (50\%) and the other 6, Duffy negative. Following the three investigative molecular approaches 


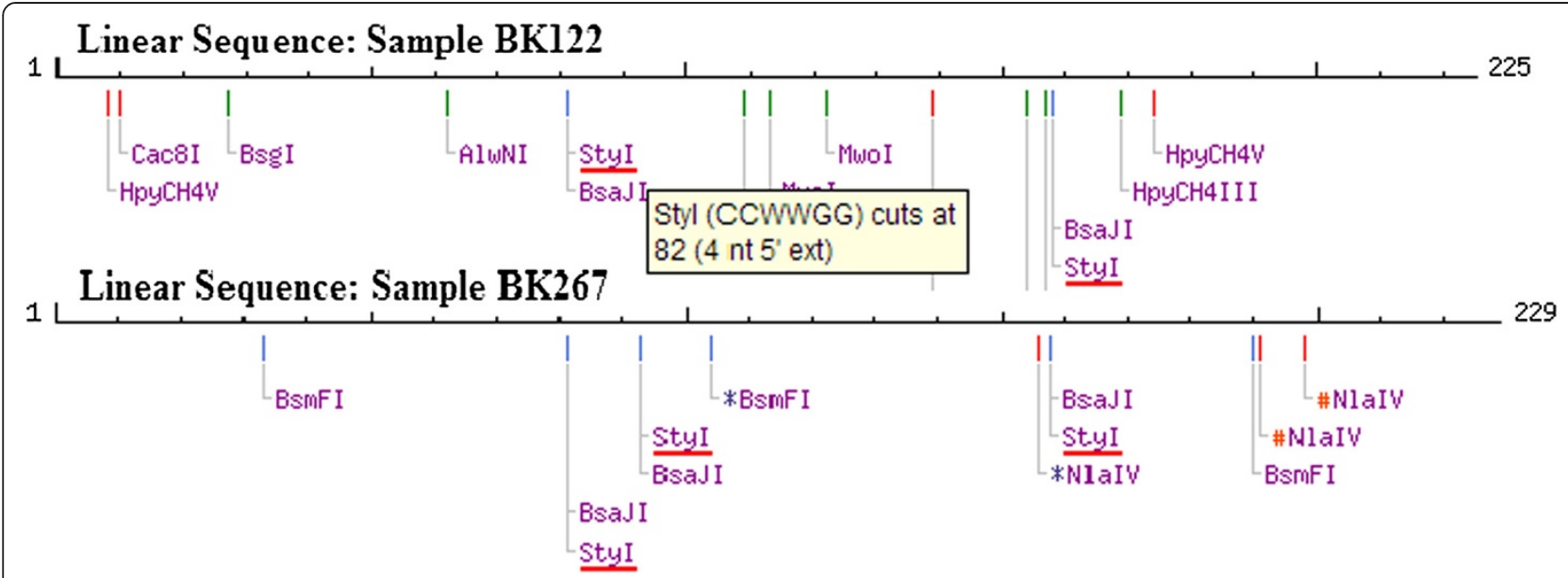

Figure 4 in silico Styl restriction map for the DARC gene promoter fragment sequence. This shows sites for Styl restriction (red horizontal bars) in two of the subjects assessed - one Duffy positive (BK122) with 2 Styl restriction sites and the other Duffy negative (BK267) with 3 Styl restriction sites.

that were used to determine the Duffy genotype of the $P$. vivax-infected individuals, two were very evident, while one was compromised by the low power of resolution of restriction fragments on a $20 \%$ native DNA PAG. The report of Duffy positive Cameroonians is a new finding. No previous study has been conducted in Cameroon to identify and determine the prevalence of the Duffy positive phenotype or genotype because of the general belief that Africans (Blacks) were largely or entirely Duffy negative and resistant to $P$. vivax infection. The findings in the present study corroborate a series of previous reports of the Duffy positive genotype on the African continent where it was thought to be non-existent and therefore a natural protecting factor for Africans against $P$. vivax infection [39,40]. Recently, Mendes and colleagues [8] showed unequivocally that the Duffy negative genotype was no longer a barrier to $P$. vivax infection, with the parasite infecting both Duffy positive and negative people, while others have implicated $P$. vivax as the causative agent in cases of severe malaria in African children $[10,16]$.

\section{The locale in Cameroon}

The south-west region of Cameroon is home to Mount Cameroon and there are several recreational and touristic sites that attract individuals of various nationalities. With the movement of people across geographic regions, it is likely that $P$. vivax was introduced in Cameroon a long time ago. The malaria vectors and parasites are equally changing their host range and/or adapting to new invasion strategies [29]. This is evident from the recent observation that $P$. knowlesi, originally a simian malaria species, can now infect humans [5]. A similar adaptation of the $P$. vivax parasite could be occurring, accounting for its increasing prevalence on the African continent. It is equally likely the $P$. vivax species may

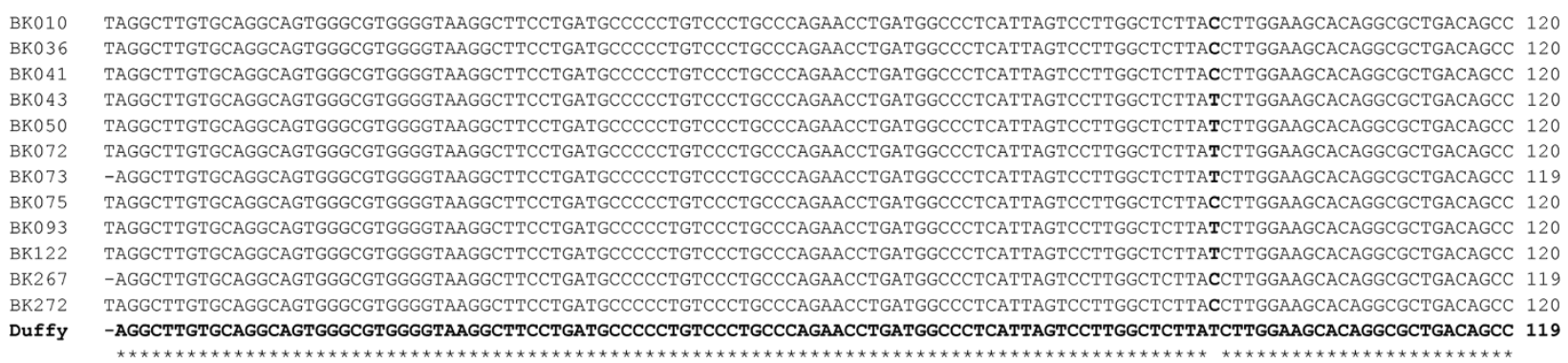

Figure 5 Multiple sequence alignment of subjects' and a Duffy positive consensus sequence, showing $\mathbf{T} \rightarrow \mathrm{C}$ point mutation. The Duffy positive consensus sequence is highlighted in bold. The alignment point indicating the $\mathrm{T} \rightarrow \mathrm{C}$ point mutation is highlighted in bold. BK010 BK272 represent the subject sample codes. Twelve subject samples were successfully aligned with the Duffy positive consensus sequence. Subjects BK010, BK036, BK041, BK075, BK267 and BK272 were Duffy negative, while subjects BK043, BK050, BK072, BK073, BK093 and BK122 were Duffy positive. 
have been there but technology did not allow their detection. The observed prevalence of $50 \%$ for the Duffy positive antigen is relatively high and therefore cannot be ignored despite the small sample size of $P$. vivax positive subjects. The finding that both Duffy positive and negative malaria asymptomatic Bolifamba residents habored $P$. vivax parasitaemia suggests that the parasite may have evolved and could be using novel receptors to gain access into erythrocytes as proposed by some research groups $[6,11,41]$. This idea was most conclusively proven correct by Ménard and colleagues [8].

\section{Conclusions}

These data provide the first definitive, molecular evidence of $P$. vivax and the Duffy positive and negative genotypes in native Bolifamba residents of Cameroon. Further investigations with a larger sample to establish the prevalence of $P$. vivax are appropriate. The results presented here indicate that there may be a need for the health sector in Cameroon to review the management of malaria to include $P$. vivax.

\footnotetext{
Abbreviations

bp: Base pairs; BSA: Bovine serum albumin; CSP: Circumsporozoite protein; DARC: Duffy antigen chemokine receptor; DMSO: Dimethyl sulfoxide; DNA: Deoxyribonucleic acid; PAG: Polyacrylamide gel; dNTP: Deoxynucleotide triphosphate; EDTA: Ethylene diamine tetraacetate; MSP: Merozoite surface protein; Mt: Mount; NEB: New England Biolab; PCR: Polymerase chain reaction; UV: Ultra violet.
}

\section{Competing interest}

The authors declare no competing financial interests.

\section{Authors' contributions}

JF-C was involved in all phases of the study, including study design, primary data collection and laboratory analyses of samples, statistical data analysis and interpretation, wrote-up the manuscript, and has given final approval of the version to be published. BW designed and supervised the study, revised the manuscript and has given final approval of the version to be published. IS designed and supervised the study, analyzed and interpreted the data, revised the manuscript, and has given final approval of the version to be published. TN-A supervised the study and also revised the manuscript, and has given final approval of the version to be published. VPKT designed and supervised the study, analysed the data and also revised the manuscript, and has given final approval of the version to be published. $\mathrm{KH}$ designed the study, supervised the study, analysed and interpreted the data, revised the manuscript, and has given final approval of the version to be published.

\section{Acknowledgements}

We thank the study subjects for their willingness to be part of the present survey. We equally acknowledge the assistance of the field research team and the chief of Bolifamba for facilitation on interaction with the villagers. We wish to acknowledge the University of Buea Biotechnology Unit and the Malaria research laboratory where the preliminary analyses took place and the Center for Rare and Neglected Diseases, Department of Biological Sciences of the University of Notre Dame, IN 46556, USA where microscopy, molecular and antigenic analyses were conducted. We are grateful to Caroline Junqueira for providing the initial $P$. vivax positive DNA that served as a positive control in our PCR analyses.

This work was supported in part by grants to KH (NIH P01 HL078826, R01 Al039071 and the University of Notre Dame), TN-A (UNDP/ World Bank/ WHO Special programme for Research and Training in Tropical Diseases Grant No.990965) and VPKT (The International Program in the Chemical Sciences (IPICS) - CAM 01 project, and Microsoft Corporation).

\section{Author details}

'Department of Microbiology and Parasitology, University of Buea, Buea, South West Region, Cameroon. ${ }^{2}$ College of Health Sciences, University of Wisconsin-Milwaukee, Milwaukee, Wisconsin, USA. ${ }^{3}$ Center for Rare and Neglected Diseases, Department of Biological Sciences University of Notre Dame du Lac, Notre Dame, Indiana 46556, USA. ${ }^{4}$ Biotechnology Unit, Department of Biochemistry and Molecular Biology, University of Buea, Buea, South West Region, Cameroon.

\section{Received: 6 January 2014 Accepted: 29 April 2014}

Published: 3 May 2014

\section{References}

1. WHO: Fact Sheet $N^{\circ}$ 94. Geneva: World Health Organization; 2013. www. who.int/mediacentre/factsheets/fs094/en. (Reviewed, March 2013. Last accessed: September 3, 2013).

2. CDC: 2013. www.cdc.gov/malaria/malaria_worldwide/impact.html. (Last accessed: September 3, 2013).

3. Malaney P, Speilman A, Sachs J: The malaria gap. Am J Trop Med Hyg 2004, 71(Suppl 2):141-146.

4. WHO: Malaria: Research results, No 38. Geneva, Switzerland: World Health Organization/TDR Report; 2001.

5. Price RN, Tjitra E, Guerra CA, Yeung S, White NJ, Austey NM: Vivax malaria: neglected and not benign. Am J Trop Med Hyg 2009, 77(Suppl 6):78-87.

6. Mendes C, Dias F, Figueiredo J, Mora VG, Cano J, de Sousa B, do Rosa'rio VE, Benito A, Berzosa P, Arez AP: Duffy negative antigen is no longer a barrier to Plasmodium vivax - Molecular evidences from the African west coast (Angola and Equatorial Guinea). PLoS Negl Trop Dis 2011, 5:e1192.

7. Rubio JM, Benito A, Roche J, Berzosa PJ, García ML, Micó M, Edú M, Alvar J: Semi-nested, multiplex polymerase chain reaction for detection of human malaria parasites and evidence of Plasmodium vivax infection in Equatorial Guinea. Am J Trop Med Hyg 1999, 60:183-187.

8. Ménard D, Barnadas C, Bouchier C, Henry-Halldin C, Gray LR, Ratsimbasoa A, Thonier V, Carod J-F, Domarle O, Colin Y, Bertrand O, Picot J, King CL, Grimberg BT, Mercereau-Puijalon O, Zimmerman PA: Plasmodium vivax clinical malaria is commonly observed in Duffy-negative Malagasy people. Proc Natl Acad Sci USA 2010, 107:5967-5971.

9. Wurtz N, Lekweiry KM, Bogreau H, Pradines B, Rogier C, Boukhary AOMS, Hafid JE, Salem MSOA, Trape J-F, Basco LK, Briolant S: Vivax malaria in Mauritania includes infection of a Duffy-negative individual. Malar J 2011, 10:336.

10. Abdallah TM, Abdeen MT, Ahmed IS, Hamdan HZ, Magzoub M, Adam I: Severe Plasmodium falciparum and Plasmodium vivax malaria among adults at Kassala Hospital, Eastern Sudan. Malar J 2013, 12:148.

11. Ryan JR, Stoute JA, Amon J, Dunton RF, Mtalib R, Koros J, Owour B, Luckhart S, Wirtz RA, Barnwell JW, Rosenberg R: Evidence for transmission of Plasmodium vivax among a Duffy antigen negative population in Western Kenya. Am J Trop Med Hyg 2006, 75:575-581.

12. Culleton RL, Mita T, Ndounga M, Unger H, Cravo PVL, Paganotti GM, Takahashi N, Kaneko A, Eto H, Tinto H, Karema C, D'Alessandro U, do Rosário V, Kobayakawa T, Ntoumi F, Carter R, Tanabe K: Failure to detect Plasmodium vivax in West and Central Africa by PCR species typing. Malar J 2008, 7:174.

13. Snounou G, Pinheiro L, Antunes AM, Ferreira C, do Rosario VE: Nonimmune patients in the Democratic Republic of Sao Tome e Principe reveal a high level of transmission of $P$. ovale and $P$. vivax despite low frequency in immune patients. Acta Trop 1998, 70:197-203.

14. Gautret $P$, Legros F, Koulmann P, Rodier MH, Jacquemin JL: Imported Plasmodium vivax malaria in France: geographical origin and report of an atypical case acquired in Central or Western Africa. Acta Trop 2001, 78:177-181

15. Poirriez J, Landau I, Verhaeghe A, Savage A, Dei-Cas E: Atypical forms of Plasmodium vivax. A propos of a case (in French). Ann Parasitol Hum Comp 1991, 66:149-154.

16. Bernabeu M, Gomez-Perez GP, Sissoko S, Niambélé MB, Haibala AA, Sanz A Théra MA, Fernandez-Becerra C, Traoré K, Alonso PL, Bassat Q, Del Portillo HA, Doumbo O: Plasmodium vivax malaria in Mali: a study from three different regions. Malar J 2012, 5:405.

17. Woldearegai TG, Kremsner PG, Kun JF, Mordmüller B: Plasmodium vivax malaria in Duffy-negative individuals from Ethiopia. Trans $R$ Soc Trop Med Hyg 2013, 107(suppl 5):328-331. 
18. Mangoni ED, Severini C, Menegon M, Romi R, Ruggiero G, Majori G: Case Report: An unusual late relapse of Plasmodium vivax malaria. Am J Trop Med Hyg 2003, 62:159-60.

19. Mendis K, Sina B, Marchesini P, Carter R: The neglected burden of Plasmodium vivax malaria. Am J Trop Med Hyg 2001, 64:97-101.

20. Kimbi HK, Awah NW, Ndamukong KNJ, Mbuh JV: Malaria infection and its consequences in school children. E Afr Med J 2005, 82:93-98.

21. Miller LH, Mason SJ, Dvorak JA, McGinniss MH, Rothman IK: Erythrocyte receptors for (Plasmodium knowlesi) malaria: Duffy blood group determinants. Science 1975, 189:561-563.

22. Akenji TN, Ntonifor NN, Kimbi HK, Abongwa EL, Ching JK, Ndukum MB, Anong DN, Nkwescheu A, Songmbe M, Boyo MG, Ndamukong KN, Titanji VPK: The epidemiology of malaria in Bolifamba, a rural community on the eastern slopes of Mount Cameroon: seasonal variation in the parasitological indices of transmission. Ann Trop Med Parasitol 2005, 99:221-227.

23. Quakyi IA, Leke RGF, Befidi-Mengue R, Tsafack M, Bomba-Nkolo D, Manga L, Tchinda V, Njeungue E, Kouontchou S, Fogako J, Nyonglema P, Harun LT, Djokam R, Sama G, Eno A, Megnekou R, Metenou S, Ndoutse L, Same- Ekobo A, Alake G, Meli J, Ngu J, Tietche F, Lohoue J, Mvondo JL, Wansi E, Leke R, Folefack A, Bigoga J, Bomba-Nkolo C, et al: The epidemiology of Plasmodium falciparum malaria in two Cameroonian villages: Simbok and Etoa. Am J Trop Med Hyg 2000, 63:222-230.

24. Basco LK, Ngane VF, Ndounga M, Same-Ekobo A, Youmba J, Abodo RTO, Soula G: Molecular epidemiology of malaria in Cameroon. XXI. Baseline therapeutic efficacy of chloroquine, amodiaquine, and sulfadoxinepyrimethamine monotherapies in children before national drug policy change. Am J Trop Med Hyg 2006, 75:388-395.

25. Nkuo-Akenji T, Ntonifor NN, Ndukum MB, Kimbi HK, Abongwa EL, Nkwescheu A, Anong DN, Songmbe M, Boyo MG, Ndamukong KN, Titanji VPK: Environmental factors affecting malaria parasite prevalence in rural Bolifamba, South West Cameroon. Afr J Hlth Sci 2006, 13:40-46.

26. Bigoga JD, Manga L, Titanji VPK, Coetzee M, Leke RGF: Malaria vectors and transmission dynamics in coastal south-western Cameroon. Malar J 2007, 6:5.

27. Wanji S, Tanke T, Atanga SN, Ajonina C, Nicolas T, Fontenille D: Anopheles species of the Mount Cameroon region: biting habit, feeding behaviour and entomological inoculation rates. Trop Med Int Health 2003, 8:643-649.

28. Fru-Cho J, Anong DN, Ayonghe S, Wanji S, Nkuo-Akenji T: The influence of seasonal variations on malaria prevalence in Mount Cameroon Region A review. J Cameroon Acad Sci 2013, 11:11-15.

29. Wanji S, Kengne-Ouafo AJ, Eyong EEJ, Kimbi KH, Tendongfor $\mathrm{N}$, Ndamukong-Nyanga JL, Nana-Djeunga HC, Bourguinat C, Sofeu-Feugaing $\mathrm{DD}$, Charvet CL: Genetic diversity of Plasmodium falciparum merozoite surface protein-1 block 2 in sites of contrasting altitudes and malaria endemicities in the Mount Cameroon region. Am J Trop Med Hyg 2012, 86:764-774.

30. Titanji VPK, Tamu VD, Nkuo-Akenji T, Sobotamu A: Immunoglobulin G and subclass responses to Plasmodium falciparum antigens: A study of highly exposed Cameroonians. Clin Chem Lab Med 2002, 40:937-940.

31. Minang JT, Gyan BA, Anchang JK, Troye-Blomberg M, Perlmann H, Achidi EA: Haptoglobin phenotypes and malaria infection in pregnant women at delivery in western Cameroon. Acta Trop 2004, 90:107-114.

32. Cheesbrough M: District Laboratory practice in tropical countries. Second Edition: Cambridge University Press, UK; 2006.

33. Kimura M, Kaneko O, Lui Q, Zhou M, Kawamoto F, Wataya Y, Otani S, Yamaguchi $Y$, Tanabe $K$ : Identification of the four species of human malaria parasites by Nested PCR that target variant sequences in the small subunit rRNA gene. Parasitol Int 1997, 46:91-95.

34. Sambrook J, Fritsch EF, Maniatis T: Molecular cloning: A laboratory manual. 2nd edition. USA: Cold Spring Harbor Laboratory Press; 1989.

35. Web site title: http://cancer-seqbase.uchicago.edu. Submitting sequencing, genotyping and colony picking orders.

36. Web site title: http://cancer-seqbase.uchicago.edu. Retrieving finished sequences and interpreting chromatograms.

37. Web site title: http://blast.st-va.ncbi.nlm.nih.gov/Blast.cgi.

38. Anong DN, Nkuo-Akenji T, Fru-Cho J, Amambua AN, Titanji VPK: Genetic diversity of Plasmodium falciparum on the slope of mount Cameroon: influence of MSP1 allelic variants on symptomatic malaria and anaemia. Ann Trop Med Parasitol 2010, 104:453-460.
39. William T, Rahman HA, Jelip J, Ibrahim MY, Menon J, Grigg MJ, Yeo TW, Anstey NW, Barber BE: Increasing incidence of Plasmodium knowlesi malaria following control of P. falciparum and P. vivax malaria in Sabah, Malaysia. PLoS Negl Trop Dis 2013, 7:e2026.

40. Langhi DM Jr, Bordin JO: Duffy blood group and malaria. Hematol 2006, 11:389-398.

41. Rosenberg R: Plasmodium vivax in Africa: hidden in plain sight? Trends Parasitol 2007, 23:193-196.

doi:10.1186/1475-2875-13-170

Cite this article as: Fru-Cho et al:: Molecular typing reveals substantial Plasmodium vivax infection in asymptomatic adults in a rural area of Cameroon. Malaria Journal 2014 13:170.

\section{Submit your next manuscript to BioMed Central and take full advantage of:}

- Convenient online submission

- Thorough peer review

- No space constraints or color figure charges

- Immediate publication on acceptance

- Inclusion in PubMed, CAS, Scopus and Google Scholar

- Research which is freely available for redistribution

Submit your manuscript at www.biomedcentral.com/submit
C Biomed Central 